\title{
Large pedunculated vulval fibroepithelial polyp
}

\author{
Jessica Rachael Gollow, ${ }^{1}$ Phillipa Robertson, ${ }^{1}$ Benjamin Cunningham ${ }^{2}$
}

${ }^{1}$ Obstetrics and Gynaecology, King Edward Memorial Hospital for Women Perth, Subiaco, Western Australia, Australia ${ }^{2}$ Obstetrics and Gynaecology, South West Health Campus, Bunbury, Western Australia, Australia

\section{Correspondence to}

Dr Jessica Rachael Gollow, jessica.gollow@health.wa. gov.au

Accepted 3 July 2019

\section{Check for updates}

(C) BMJ Publishing Group Limited 2019. No commercial re-use. See rights and permissions. Published by BMJ.

To cite: Gollow JR, Robertson P, Cunningham B. BMJ Case Rep

2019;12:e230449.

doi:10.1136/bcr-2019230449

\section{DESCRIPTION}

A 19 year-old woman presented to a regional emergency department with an 18-month history of a slowly enlarging and painless $20 \mathrm{~cm}$ right-sided vulval mass (figure 1). The location and size of the mass had severely impacted her daily living and self-confidence, resulting in deferral of her university studies and social isolation.

Further history revealed no associated symptoms including fever, weight loss or anorexia. She described a regular 28-day cycle since menses, aged 13 , and had no risk factors for sexually transmitted infections. She had a past medical history of anxiety, well managed with fluoxetine and had no prior surgical procedures.

On examination, the patient was systemically well with no lymphadenopathy. There was vulval asymmetry due to the overwhelming size of the mass, measuring $205 \times 165 \times 47 \mathrm{~mm}$, with a broad vascular pedunculated stalk. There was an ulcerated area measuring $135 \times 140 \mathrm{~mm}$.

After a multidisciplinary discussion with the tertiary gynae-oncology team, the patient was taken to theatre for examination under anaesthesia and excision. Two straight clamps were placed at the proximal margin of the polyp and it was excised using sharp dissection between the clamps. Due to the significant vessels in the stalk, interrupted haemostatic sutures were placed superiorly to the remaining clamp. Once haemostasis was confirmed the skin was closed using interrupted mattress sutures with 2.0 vicryl rapide.

The specimen was sent to a tertiary centre for histopathology examination, which confirmed a fibroepithelial polyp (figure 2) weighing $818 \mathrm{~g}$. The patient had an uncomplicated postoperative course. Haemostatic sutures where removed at day 5 , and the skin sutures at day 10. Excellent wound healing was observed during the 6th and 12th week gynaecology reviews, and the patient was pleased with cosmesis before being discharged from the team's care. A polyp of this size and location is rare and no similar cases were found on the PubMed database. ${ }^{1}$

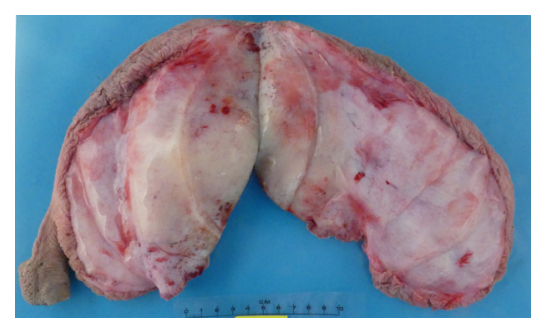

Figure 1 Pedunculated vulval fibroepithelial polyp.

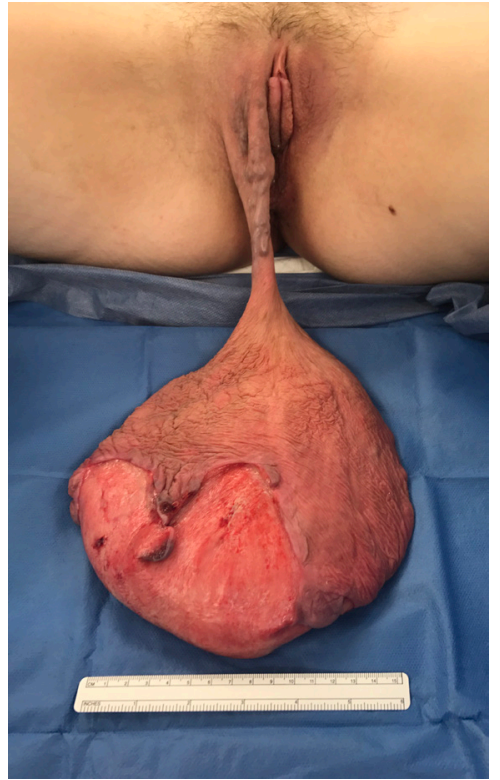

Figure 2 Cross-section of vulval fibroepithelial polyp.

Learning points

Anatomical examinations of the genital tract need to be undertaken in a sensitive and culturally appropriate manner.

- A multidisciplinary approach to unusual or uncommon presentations is important to ensure diagnoses are not missed and appropriate management plans are enacted.

- Fibroepithelial polyps are usually less than a centimetre in size but should be included as a differential diagnosis for larger vulval masses.

Contributors JRG, PR and BC formulated the idea of the case write up. JRG wrote the case report. PR and BC contributed to the editing of the written case report.

Funding The authors have not declared a specific grant for this research from any funding agency in the public, commercial or not-for-profit sectors.

Competing interests None declared.

Patient consent for publication Obtained.

Provenance and peer review Not commissioned; externally peer reviewed.

\section{REFERENCE}

1 Elwood H. Fibroepithelial polyp. http://www.pathologyoutlines.com/ topic/skintumornonmelanocyticfibroepithelialpolyp.html (Accessed 14 Nov 2018). 
Images in...

Copyright 2019 BMJ Publishing Group. All rights reserved. For permission to reuse any of this content visit https://www.bmj.com/company/products-services/rights-and-licensing/permissions/

BMJ Case Report Fellows may re-use this article for personal use and teaching without any further permission.

Become a Fellow of BMJ Case Reports today and you can:

- Submit as many cases as you like

Enjoy fast sympathetic peer review and rapid publication of accepted articles

Access all the published articles

- Re-use any of the published material for personal use and teaching without further permission

Customer Service

If you have any further queries about your subscription, please contact our customer services team on +44 (0) 2071111105 or via email at support@bmj.com.

Visit casereports.bmj.com for more articles like this and to become a Fellow 